\title{
THE ECLECTIC PARADIGM OF INTERNATIONAL PRODUCTION: A RESTATEMENT AND SOME POSSIBLE EXTENSIONS
}

\author{
John H. Dunning* \\ University of Reading and Rutgers University
}

\begin{abstract}
This article reviews some of the criticisms directed towards the eclectic paradigm of international production over the past decade, and restates its main tenets. The second part of the article considers a number of possible extensions of the paradigm and concludes by asserting that it remains "a robust general framework for explaining and analysing not only the economic rationale of economic production but many organisational and impact issues in relation to MNE activity as well."
\end{abstract}

\section{INTRODUCTION}

The concept of the eclectic paradigm of international production ${ }^{1}$ was first put forward by the present author in 1976 at a presentation to a Nobel Symposium in Stockholm on The International Allocation of Economic Activity. ${ }^{2}$ The intention was to offer a holistic framework by which it was possible to identify and evaluate the significance of the factors influencing both the initial act of foreign production by enterprises and the growth of such production. The choice of the word eclectic was an ambitious yet deliberate one. It was meant to convey the idea that a full explanation of the transnational activities of enterprises needs to draw upon several strands of economic theory; and that foreign direct investment is just one of a number of possible channels of international economic involvement, each of which is determined by a number of common factors.

It is accepted that, precisely because of its generality, the eclectic paradigm has only limited power to explain or predict particular kinds of international production; and even less, the behaviour of individual enterprises ${ }^{3}$. But this deficiency, if it is a deficiency, which some critics have alleged, could no less be directed at attempts to formulate a general but operationally testable paradigm of international trade. The classical and neoclassical theories of trade, for example, while still having wide explanatory powers for most kinds of inter-industry trade are quite inadequate to explain much of intra-industry trade 4 . Indeed it is perhaps worth emphasizing that the point at which the Heckscher-Ohlin-Samuelson (H-O-S) theory of trade fails is precisely that at which the modern paradigm of international production starts, namely the point at which there are positive transaction costs in intermediate

* John H. Dunning is currently Seth Boyden Distinguished Professor of International Business at Rutgers University. On return to the University of Reading in 1988, he will take up an ICI Research Professorship in International Business.

Comments on an earlier draft of this paper by Mark Casson, John Cantwell and three anonymous referees are gratefully acknowledged.

Received: June 1985; Revised: September 1986 \& March 1987; Accepted: June 1987. 
goods markets. ${ }^{5}$ The difference between the neo-technology and other modern theories of trade and those of international production is that, while the former implicitly assume that all goods are exchanged between independent buyers and sellers across national frontiers, the latter explicitly postulate that the transfer of intermediate products is undertaken within the same enterprises. In other words, without international market failure, the raison d'etre for international production disappears. But once it exists, explanations of trade and production may be thought of as a part of a general paradigm based upon the international disposition of factor endowments, and the costs of alternative modalities for transacting intermediate products across national boundaries. This is the central theme of this paper.

\section{CRITICISMS OF THE ECLECTIC PARADIGM}

\section{Are Competitive or Ownership Advantages Necessary to Explain International Production?}

In its original form, the eclectic paradigm stated that the extent, form, and pattern of international production was determined by the configuration of three sets of advantages as perceived by enterprises. ${ }^{6}$ First, in order for firms of one nationality to compete with those of another by producing in the latter's own countries, they must possess certain advantages specific to the nature and/or nationality of their ownership. These advantages - sometimes called competitive or monopolistic advantages - must be sufficient to compensate for the costs of setting up and operating a foreign value-adding operation, in addition to those faced by indigenous producers or potential producers.

In our 1976 paper we identified three types of ownership-specific advantages: (a) those that stem from the exclusive privileged possession of or access to particular income generating assets, (b) those that are normally enjoyed by a branch plant compared with a de novo firm, and (c) those that are a consequence of geographical diversification or multinationality per se. In a later typology (Dunning 1983a, 1983b), we distinguished between the asset (Oa) and transaction (Ot) advantages of multinational enterprises (MNEs). ${ }^{8}$ While the former arise from the proprietary ownership of specific assets by MNEs vis-à-vis those possessed by other enterprises (i.e., of type (a) above, which can only occur in a situation of structural market distortions $)^{9}$, the latter mirror the capacity of MNE hierarchies vis-à-vis external markets to capture the transactional benefits (or lessen the transactional costs) arising from the common governance of a network of these assets, located in different countries.

The distinction between structural and transactional market imperfections is an important one (Dunning and Rugman 1985). Clearly the relevance of each in determining the ownership advantages of MNEs will vary according to the characteristics of firms, the products they produce, the markets in which they operate, and whether the competitive process is viewed from a static or dynamic perspective. Certainly earlier analyses of foreign direct investment - particularly those of the Hymer $(1960,1976)$ tradition - tended to emphasize the former kind of imperfection; but, similarly, so do contemporary economists working in the area of innovation 
and technological development (e.g., Pavitt 1987, Cantwell 1986); and business analysts seeking to identify the systemic advantages of globally-oriented enterprises (e.g., Pralahad and Doz 1987; Kogut 1983, 1985a). By contrast, the modern theory of the MNE qua MNE (e.g., as summarized by Teece 1986 and Casson 1987) tends to emphasize transactional market failure as the main raison d'etre for international production. The two kinds of imperfection are, of course, often interrelated, particularly in a dynamic market situation, ${ }^{10}$ and there is a growing consensus that the most successful MNEs are those that are best able to nurture and exploit both asset and transactional ownership advantages.

The second condition for international production is that it must be in the best interests of enterprises that possess ownership-specific advantages to transfer them across national boundaries within their own organizations rather than sell them, or their right of use to foreign-based enterprises. This immediately suggests that MNEs perceive that the international market place is not the best modality for transacting intermediate goods or services. The reasons for the internalization of markets has been explored in considerable detail in the literature. ${ }^{11}$ Suffice to reiterate here that three main kinds of market failure are usually identified as: (i) those that arise from risk and uncertainty as, for example, those succinctly analyzed by Vernon (1983); (ii) those that stem from the ability of firms to exploit the economies of large-scale production, but only in an imperfect market situation; and (iii) those that occur where the transaction of a particular good or service yields costs and benefits external to that transaction, but that are not reflected in the terms agreed to by the transacting parties. ${ }^{12}$ The desire by firms to integrate different stages of the value-added chain, to engage in product diversification, or to capture the economies of the use of complementary assets (Teece 1986), originate from the presence of one or other of these forms of transactional market failure - even though the motives for internalization may be expressed rather differently (e.g., to safeguard supplies of essential inputs, to ensure the quality of end products, to guarantee markets, to protect property rights, to allow price discrimination, to spread the costs of shared overheads and so on). The greater the perceived costs of transactional market failure, the more MNEs are likely to exploit their competitive advantages through international production rather than by contractual agreements with foreign firms. By contrast, the higher the administrative costs of hierarchies and/or the external diseconomies (or disbenefits) of operating a foreign venture (e.g., as shown by the Bhopal disaster), the more probable the latter vehicle (or at least a jointly shared equity stake) will be preferred.

In such cases where there is no external market for the competitive advantages of MNEs, the distinction between ownership and internalization advantages may seem irrelevant. Indeed some writers (notably Buckley and Casson 1985; and Casson 1987) have argued that the failure of international intermediate product markets is both a necessary and sufficient condition to explain the existence of MNEs. Yet we believe it is not only useful but logically correct to distinguish between the capability of MNEs to internalize markets, and their willingness to do so. For while the latter may explain why hierarchies rather than external markets are the vehicle by which transactional ownership advantages (Ot) are transferred across national boundaries, it is the former which explains why these advantages are 
exploited by one group of MNEs rather than another, or by MNEs rather than firms indigenous to the country of production. ${ }^{13}$ This point has in fact been acknowledged by Casson (1986a, p. 46).

Certainly in the exploitation of specific intangible assets (Oa) (e.g., a patent or trade mark), firms often have a choice between using the external market or not. Here the distinction between asset generation, or acquisition, and asset usage is an important one. We would accept with Rugman (1981) that, if an ownership advantage is either created by or becomes the exclusive property of a particular enterprise, it has in some sense "internalized" the market for its use, ${ }^{14}$ but we believe this to be a questionable extension of the interpretation of a term that originally and quite specifically was intended to convey a response to transactional rather than structural market failure. ${ }^{15}$

\section{Locational Advantages: Structural and Transactional Market Failure}

The third strand of the eclectic paradigm is concerned with the "where" of production. Enterprises will engage in foreign production whenever they perceive it is in their best interests to combine spatially transferable intermediate products ${ }^{16}$ produced in the home country, with at least some immobile factor endowments or other intermediate products in another country. While, in the eclectic paradigm, the advantages or disadvantages of particular locations are treated separately from the ownership advantages of particular enterprises, and while the market for these advantages are internalized; the decision on where to site a mine, factory or office, is not independent of the ownership of these assets nor of the route by which they or their rights are transacted. Similarly, the choice of location may be prompted by spatial market failure: historically the imposition of trade barriers has led to a lot of foreign manufacturing investment by MNEs. At the same time a reduction in transport costs and the formation of customs unions or regional trading blocs (e.g., EEC and LAFTA) have prompted greater regional specialization of production by MNEs (Dunning 1987b).

Once more a distinction needs to be drawn between the different kinds of market imperfections that may influence the locational decisions of MNEs. Structural market distortions - e.g., those arising from some (but not all) kinds of government intervention, ${ }^{17}$ which affect the costs and/or revenues of producing in different locations - may either encourage or discourage inward direct investment (Guisinger 1985). On the other hand, even without such distortions MNE activity would still occur wherever there are transaction gains likely to result from the common governance of activities in different locations. Such advantages include enhanced arbitrage and leverage opportunities, the reduction of exchange risks and better coordination of financial decision taking, the protection afforded by a hedged marketing or multiple sourcing strategy, and the possibility of gains through transfer price manipulation, leads and lags in payments, and so on (Kogut 1985b, Dunning 1987a).

The ability to generate and sustain such ownership advantages itself strengthens the competitive position of MNEs vis-à-vis uninational firms. But because transactional market failure is sometimes country-specific, it has locational implications as well. To this extent, Rugman is on the right lines when he refers 
to the MNE as "internalising exogenous spatial imperfections" (Rugman 1981); but his analysis better explains the common ownership of MNE subsidiaries in different locations, rather than why particular subsidiaries are located where they are.

\section{Specific or General Theories of International Production?}

It is then the juxtaposition of the ownership-specific advantages of firms contemplating foreign production, or an increase in foreign production, the propensity to internalize the cross-border markets for these, and the attractions of a foreign location for production which is the gist of the eclectic paradigm of international production. But the identification and value of the specific ownership, location and internalisation (OLI) parameters that will influence individual MNEs in any particular production decision will vary according to the motives underlying such production. The parameters influencing a MNE to invest in a copper mine in New Guinea are unlikely to be the same as those influencing investment by a Japanese color television company in the United States; while those determining the pattern of rationalized production in the EEC by a large and geographically diversified US motor vehicles MNE will be different from an investment by a Korean construction management company in Kuwait.

However, the eclectic paradigm does allow one to go a step further by relating the OLI configuration facing MNEs to a number of structural or contextual variables. We have previously identified the more important of these as country, industry (or activity) and firm-specific (Dunning (1981)). For example, the asset advantages (Oa) of particular MNEs may be expected to vary according to the factor endowments and other characteristics of the countries from which they originate, and/or in which they operate: and the technological and other features of the activities in which they engage. The fact that such assets may be the exclusive property of particular firms, and be mobile across national boundaries, does not negate the possibility that their source may be explained by the international disposition of country-specific and immobile endowments. To this extent, one is back to H-O$\mathrm{S}$ type trade theory, but with two differences. The first is that the goods and services traded are intermediate rather than final products; and the second is that the eclectic paradigm allows for the role of governments, in affecting, by the political systems they operate and the economic policies they pursue the real (as opposed to the potential) value of the resources contained within their jurisdictional areas. ${ }^{18}$ Several writers, e.g., Franko (1976), Ergas (1984), Davidson (1976) and Pavitt (1987), have demonstrated that the kind of innovatory advantages generated by MNEs reflect the resource endowments, markets, culture, attitudes and institutional framework of their home countries. ${ }^{19}$

It requires but a small modification of the factor endowment approach to explain why some types of economic activity are more prone to internalization than others. Again the spatial disposition of resource endowments and international transport costs are the key variables. If the capacity to create a particular asset is ubiquitous, and the right to its use can be disseminated at zero cost, then international production is unlikely; it is also improbable where the competitive advantages of firms rest not in the exclusive possession of specific assets, but in the access to immobile 
but nonspecific factor endowments on favorable terms. Thus, a combination of the resource requirements of particular economic activities, their geographical disposition, and the transfer costs of their output, helps to explain some of the operations of MNEs.

But only some! For example, it does little to explain the cross-hauling of investment in the same industries by MNEs of different nationalities; or the fact that some countries display similar patterns of international production. The explanation is limited because it ignores transactional market failure, which itself varies between countries and types of economic activities. Without such failure, but with an uneven distribution of resource endowments, trade in intermediate products would be conducted through external markets. With an even distribution of resource endowments, but with market failure, then the only advantage which MNEs qua MNEs possess is their capability to better overcome international transactional imperfections than their uninational rivals (Dunning 1986c).

\section{Does the Eclectic Paradigm Insufficiently Allow for Firm-Specific Behavioural Differences?}

We now turn to consider a structural variable, which some business analysts regard as the most crucial of all in influencing the level and pattern of international production. This is the strategic response of decision takers within MNEs to a set of economic and other variables; and the way the idosyncratic behaviour of firms might influence and respond to cross-border market failure.

A cursory review of the international profiles of the leading MNEs identified by Stopford (1982) reveals that in some sectors (e.g., consumer electronics, motor vehicles, pharmaceuticals, etc.), there are as many differences between the characteristics of MNEs in the same sector as there are between MNEs in different sectors. Moreover, since these firms rarely supply identical products or the same range of products, or produce on the same (or similar) points of the value-added chain, or sell in the same markets; and since they have differing capabilities for, and a need of, international production; it follows that not only are they faced with a different set of strategic options, but that their evaluation of these options, and the risks attached to them, will vary. Indeed, the risk diversification thesis (Rugman 1979) asserts that different firms may view identical investment opportunities offered by a particular country differently, inter alia, according to the distribution of their existing portfolios and their attitudes towards uncertainty. For these, and other reasons identified in the business literature, firm-specific characteristics may be a crucial determinant of the response by MNEs to any particular OLI configuration.

While there have been some attempts to model the strategic behaviour of firms towards their foreign operations, ${ }^{20}$ they have not generally been incorporated into the mainstream of international production theory. The exceptions are the product cycle, oligopolistic strategy and risk minimization models. The first two (Vernon 1974, Knickerbocker 1973) look upon much of foreign production as a strategy by firms to protect or gain an ownership-specific advantage vis-à-vis their rivals; the implication being that, in a more competitive and less risky environment, firms would have less impetus to engage in international direct investment (Vernon 1983). 
Evidence of such strategies of oligopolists include the bunching of the timing of foreign investment in some sectors (Dunning 1986a; Knickerbocker 1973; Graham 1978, 1985; Lake 1976a and b). The risk minimization hypothesis argues that, other things being equal, firms will prefer to diversify the geographical portfolio of their investments. This concept may be extended to incorporate nonfinancial portfolio behaviour. Clearly, whether or not a firm adopts a global product or marketing strategy, or chooses to engage in multiple sourcing (Kogut 1983, 1985b), reflects not only on its ability to do so (which inter alia will be function of its size, product structure and existing overseas commitments), but on its perceptions of the resulting costs and benefits.

To what extent can differences in the behaviour of firms be embraced by the OLI framework? The answer is they can, insofar as it is possible to identify and evaluate systematic patterns of such behavior. Purely random or idiosyncratic actions by particular MNEs cannot be so easily incorporated. But no less is this true if one was attempting a generalized theory of the uninational firm. Such theories as abound in the literature are really theories of the behaviour of firms in the sense that it is not the behaviour of any particular firm they are trying to predict but that of a group of firms, or of a representative (or average) firm of that group. They usually assume two things. First, that firms have broadly similar goals; and second, that they respond to economic signals to advance these goals in a rational and consistent way. When neither condition exists, it is not possible to offer any generalized explanations of behaviour; which, indeed, is exactly what some business analysts would claim.

We do not accept that such a drastic course is either desirable or justifiable; indeed, we believe that, for most firms, that part of business conduct which is purely idiosyncratic is probably very small. However, we are persuaded that the interface between the economic and behavioral theories of the firm does need more explicit and systematic analysis. While there is general agreement about the main country and industry characteristics likely to influence each of the main components of the eclectic paradigm, much less attention has been given to identifying the key attributes of firms - and especially those that might be identified as operational or strategically based - that may affect their response to any particular configuration of OLI parameters.

There are now signs of this happening. Some of the recent literature on global dimensions of business ${ }^{21}$ is replete with attempts to identify the strategically-related characteristics of firms most likely to be associated with a robust international posture. These include their long-term goals and perspectives, the nature and scope of their core assets, their attitude to innovation and change (are they leaders or followers in their industry, are they innovators or imitators?), the range and segment of critical markets served, their attitude to risk and uncertainty, their operational flexibility, their organizational and cultural ethos, the entrepreneurial initiative of their chief decision takers and their willingness and capacity to conclude crossborder alliances.

There has been little empirical research on these and other behavioral-related variables in influencing the extent and pattern of international production. In 1972 Horst concluded that, apart from size, he could identify no firm-specific variable which 
satisfactorily explained the degree of multinationality of US-owned firms across industries and countries. More recently a study undertaken on the modes of transferring technology between countries but within firms (Davidson and McFeteridge 1984, 1985) revealed that such variables as existing overseas commitment, research intensity, and degree of product diversification were positively and significantly correlated with the extent of a firm's internalization. Most recently of all, Porter (1986) has developed a model that relates the extent to which different types of firms seek to coordinate their cross-border value-adding investments, with the propensity to centralise or decentralize the location of these investments. Porter describes a globally or geocentrically-oriented MNE as one that operates an extensive network of foreign affiliates, the activities of which are subject to a high degree of centralized coordination. Such an MNE is to be distinguished from a multidomestic company, that, through its loosely organised overseas subsidiaries, pursues a series of country centered strategies; or, indeed, from one that adopts a simple strategy with a geographically concentrated configuration of activities. ${ }^{22}$

In conclusion, it may well be that there are some behavioral-related variables of firms that have not been successfully incorporated into the eclectic paradigm. Insofar as it is possible to identify those that might influence the response of groups of enterprises to a given OLI configuration, there is no reason why this could not be done. But where no general systematic or consistent response of firms to changes in exogenous variables can be discovered, any attempt to generalize about the causes of international production is thwarted from the start.

\section{The Aliber Theory of Foreign Direct Investment}

Let us now briefly turn to Robert Aliber's (1983) dissatisfaction with the eclectic paradigm and, indeed, with all theories that take some measure of the foreign activities of enterprises as their starting point of interest. This reflects Aliber's view that the key attribute of a MNE is not the fact that it engages in foreign production, but that it finances at least part of this production in its home currency. He is, then, primarily interested in the export of direct investment as a means of financing foreign capital expenditure rather than as a channel by which an enterprise transfers nonfinancial resources between countries, and controls the use of such resources once transferred. He would appear to believe that the extraterritorial expansion of firms per se raises no issues not already addressed by the theory of the domestic firm. Rather, the uniqueness of the MNE is its ability to dominate its geographically dispersed assets in different currencies, and by so doing, to take advantage of structural or transactional imperfections in international capital and foreign exchange markets.

Inasmuch as scholars are entitled to study subjects of interest to them, we have no dispute with Aliber. We would, however, challenge his implicit assumption that while differences in kind exist between national and international financial markets, this is not the case for nonfinancial markets, such as these for technology and management services. Moreover, it seems to us that Aliber restricts his consideration of foreign direct investment to situations in which enterprises invest in different currency areas. While this may be usually the case, it is by no means universally so. 
In any event, we do not find Aliber's thesis incompatible with the eclectic paradigm. The very fact that firms, by their presence overseas, may be able to denominate their assets and goods in different currencies, could give them a competitive or an ownership-specific edge over uninational firms. This advantage will be the more pronounced the greater the degree of structural or transactional failure in international capital and/or exchange markets, and the better equipped MNEs are to internalize these markets. Yet, by themselves, these advantages are not sufficient to explain either the amount or distribution of foreign direct investment. For example, expected profits (other than those resulting from the internalization of imperfect financial markets) are not independent of the locations in which investments are made, nor of the ability of MNEs to appropriate economic rent by internalizing nonfinancial markets.

It is not our purpose to offer a detailed critique of the Aliber hypothesis, ${ }^{23}$ but rather to suggest that, insofar as imperfections do exist in the markets in which he is interested, these may affect both the way in which capital expenditure by MNEs is financed, and the geographical distribution of international production. Similarly, the factors identified in the eclectic paradigm as influencing the foreign activities of firms, may directly, by their impact on capital and exchange markets, and/or, indirectly, by affecting the total capital expenditure by MNEs, have no less a bearing on their financing of these activities. We would then assert that, in support of his own theory, Professor Aliber must take cognizance of the nonfinancial aspects of the international operations of firms.

\section{The Kojima Hypothesis ${ }^{24}$}

As originally propounded (Kojima 1978, 1982), Professor Kojima's theory of foreign direct investment is an extension of the neoclassical theory of trade to embrace cross-border transactions of intermediate products (e.g., technology, management skills etc.). It is primarily a normative theory, and views the MNE as an instrument by which the comparative trading advantage of nation states may be better advanced. Hence his prescription that a home country should invest abroad in sectors that require intermediate (but internationally mobile) products that it is comparatively well suited to supply; but that need to be combined with nontransferable inputs in which the host country is relatively well endowed. In this case, foreign direct investment acts both as a catalyst to trade and as an arbitrager for improving the international allocation of economic activity.

Kojima criticizes the eclectic paradigm for being too micro- or business-oriented, and claims it is of limited use for policy formation by home or host countries. But, as we have sought to demonstrate from the perspective of the United Kingdom (Dunning 1981, chap. 6), many of the normative implications of our paradigm are entirely consistent with Kojima's recommendations. This is particularly the case for resource-based and import substitution investment, where the export of intermediate products by MNEs to countries best suited to engage in further value added activities, either circumvents artificially imposed impediments to trade, or better promotes the dynamic comparative advantage of the participating countries.

However, even as a prescriptive macroeconomic model, the Kojima approach is deficient in two major respects. First, since it is neoclassical in its stance, it can 
neither explain, nor evaluate the welfare implications of those types of foreign direct investment prompted by the desire to rationalize international production and to benefit from the common governance of cross-border activities (i.e., Ot advantages). The eclectic paradigm can and does embrace such international production. Second, and related to the first, Kojima largely ignores the essential characteristic of MNE activity - namely, the internalization of intermediate product markets; and where he does take this into account, he always seems to assume that the resulting allocation of resources is less desirable to that which would have been dictated by the market (Kojima 1978, chap. 9). This is because Kojima is locked into a neoclassical paradigm of perfect competition that negates the very possibility of market failure. In his scenario, the MNE can never be the most efficient agent for transferring resources across national boundaries, simply because its very existence implies a second-best transactional situation.

Again, this does not seem to be of much practical value to governments in their formulation of policy towards MNEs. Firms do not exist in a riskless or timeless vacuum; many individual transactions do give rise to external costs or benefits; the exploitation of economies of scale may not be possible without the presence of some structural market distortion; some product differentiation may be desirable; and some property rights may require, at least temporary protection against their infringement or dissipation, if they are to be supplied at all.25 The question at issue is surely that, given the viable alternatives, and over an appropriate time period, can the resource allocation between countries be improved by foreign direct investment or the operation of MNEs?

Empirically, the alleged dichotomy between the patterns of Japanese and U.S. direct investment is a false one. As Mason (1980) has well argued, such differences as do exist reflect the different stages in the evolution of Japanese and American MNEs as much as anything else. The eclectic paradigm would suggest that, in a world free of trade restrictions, the initial act of foreign direct investment would normally occur in those sectors that use intermediate products in which the investing country has a comparative advantage. This act would be welfare-creating wherever the price charged for the intermediate output fairly reflected its social opportunity cost, and the resources released within the home country are deployed in a way consistent with the principle of comparative advantage. We would accept that most Japanese foreign investment of the 1960s and '70s was of this kind. However, as firms become more multinational and take a more global perspective of their foreign operations, their ownership advantages become less based on the exclusive possession of particular intangible assets, which are country-specific in origin, and more on their ability to successfully coordinate and manage a network of geographical activities. These transaction costs-minimizing advantages - which tend to be firmrather than country-specific in origin - were largely the property of the larger US and European MNEs in the 1960s and 1970s; only now, in the later 1980s, are they beginning to be exploited by their Japanese counterparts.

\section{A RESTATEMENT OF THE ECLECTIC PARADIGM}

So much for some of the criticisms of the eclectic paradigm. In consideration of these, and on further reflection, we are now fully persuaded that any holistic 
theory of international production must draw upon two inter-related strands of economic analysis. The first is the neoclassical theory of factor endowments, extended to embrace intermediate products, and to allow for the possibility that some endowments are mobile across national boundaries. Ceteris paribus, the more uneven the geographical distribution of factor endowments, the more international production is likely to take place. The nature of such production will resemble that of $\mathrm{H}$ O-S trade in that it is inter-industry in character. The second strand is the theory of market failure, which is relevant to explaining not only the location of some kinds of economic activity across national boundaries, but also the division of that activity between multinational and uninational firms. ${ }^{26}$ Ceteris paribus, the higher the transaction costs of using the market as a transactional model, and the greater the efficiency of MNEs as coordinators of geographically dispersed activities, the more international production is likely to take place. Such production may be either inter- or intra-industry in character; but that based on Ot advantages alone is more likely to be of the latter kind (Dunning and Norman 1985).

In Figure 1, we set out the relationship between these two intellectual strands and the analytical constructs set out in this paper. We believe this figure is selfexplanatory and needs no further elaboration. Figure 2 illustrates the relevance of these two basic elements of the eclectic paradigm in explaining the three main kinds of international production. We also would reiterate an earlier observation, that as an enterprise develops a network of foreign affiliates, which it treats as part of a global system of activities, the relative importance of factor endowments in explaining changes in international production is likely to decrease; and that of market failure likely to increase. ${ }^{27}$

\section{SOME POSSIBLE EXTENSIONS OF THE ECLECTIC PARADIGM}

It is our contention that the eclectic paradigm provides a rich and robust framework not only for analyzing and explaining the determinants of international production and how this varies between firms, industries, and countries, and over time; but for our understanding of a wide variety of other MNE-related issues. In this paper, we will illustrate six possible directions in which work on the paradigm might be further developed.

\section{A More Formal Modeling of the Paradigm}

There is need for a more systematic and rigorous modeling of the explanation of different types of international production by the use of specifically and operationally testable OLI parameters. ${ }^{28}$ Given these types, the variations within them may be explained by structural variables as identified by empirical research. ${ }^{29}$ Some work by trade economists, notably Ethier (1986), Markussen (1984) and Helpman (1984), is currently proceeding in this direction. There is also need for formal modeling of the MNE as an organizational mechanism and/or choice of modality of resource transfer. Again some progress has been made by Grosse (1985), Casson (1985) and Horstman and Markussen (1986), but more work requires to be done. Finally, there is need for a more systemic approach to examining the strategic behavior of MNEs - using, for example, such tools as game theoretic and network analysis. 
FIGURE 1

\section{The Endowment/Market Failure Paradigm of International Production}

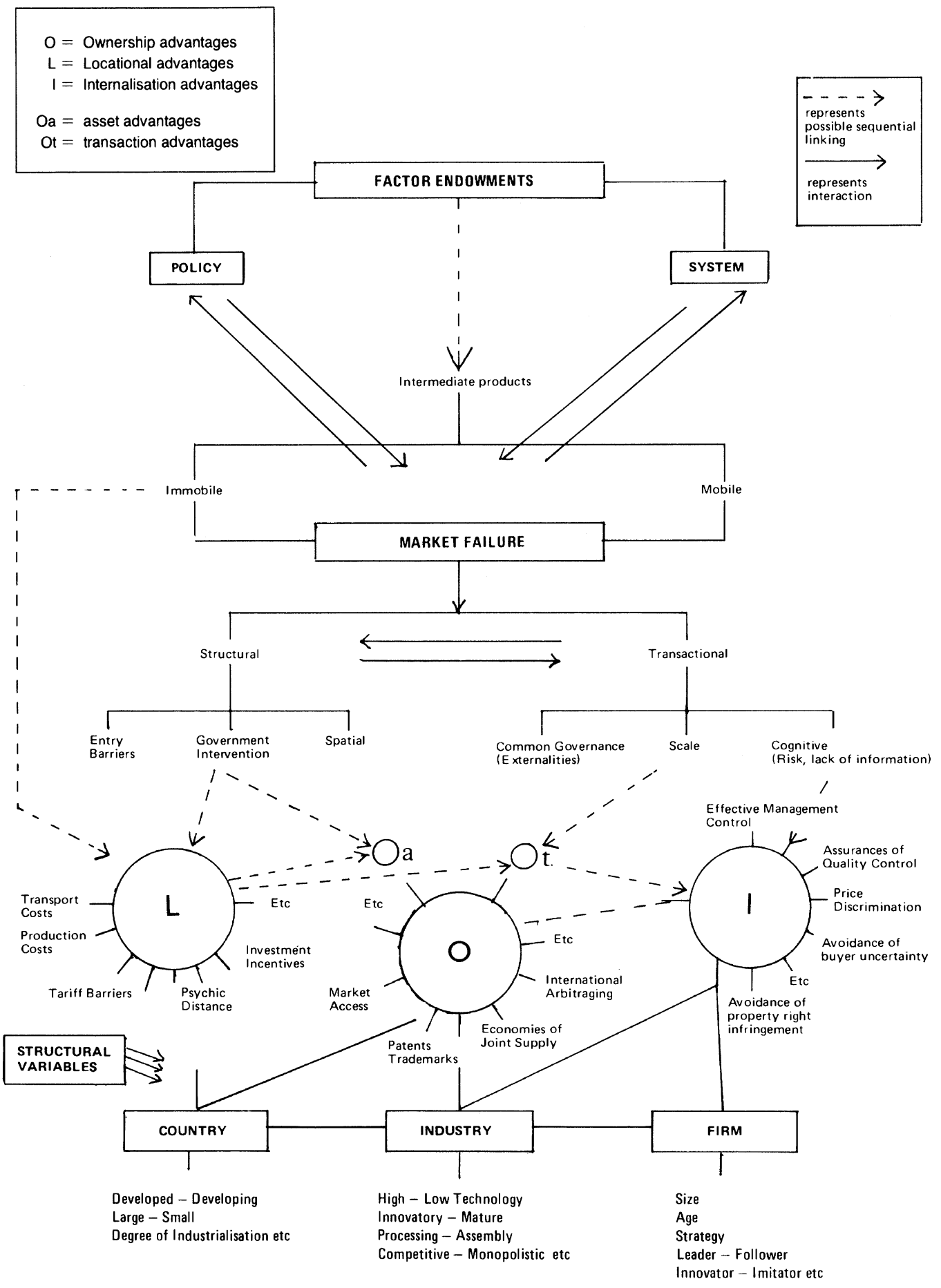


FIGURE 2

Illustration of Use of Factor Endowment/Market Failure Paradigm in Explaining Three Main Forms of International Production

\begin{tabular}{|c|c|c|c|}
\hline $\begin{array}{l}\text { Main Types of } \\
\text { International } \\
\text { Production }\end{array}$ & $\begin{array}{l}\text { Factor Endowments } \\
\text { (Affecting geographical } \\
\text { distribution of } L \text { ) }\end{array}$ & $\begin{array}{l}\text { Structural Marke } \\
\text { (Affecting } L \text { and } O a)\end{array}$ & $\begin{array}{l}\text { Failure } \\
\text { Transactional } \\
\text { (Affecting Ot, L and I) }\end{array}$ \\
\hline $\begin{array}{l}1 \text { Market Seeking } \\
\text { (import substituting) }\end{array}$ & $\begin{array}{l}\text { Home country for crea- } \\
\text { tion of Oa (= mobile } \\
\text { endowments/interme- } \\
\text { diate products) } \\
\text { Host country advantage } \\
\text { in immobile endow- } \\
\text { ments with which Oa } \\
\text { have to be used eg. nat- } \\
\text { ural resources, some } \\
\text { kinds of labour } \\
\text { Market size \& character }\end{array}$ & $\begin{array}{l}\text { Firm specific = } \\
\text { proprietary Oa (eg. } \\
\text { Knowledge) privi- } \\
\text { leged access to } \\
\text { inputs } \\
\text { Restrictions on trade } \\
\text { in goods } \\
\text { (a) natural } \\
\text { (transport costs) } \\
\text { (b) artificial } \\
\text { (import controls) } \\
\text { Oligopolistic market } \\
\text { structure }\end{array}$ & $\begin{array}{l}\text { Search and negoti- } \\
\text { ating costs } \\
\text { Protection against } \\
\text { misrepresentation or } \\
\text { infringement of prop- } \\
\text { erty rights } \\
\text { Economics of bulk } \\
\text { purchasing } \\
\text { Part of international } \\
\text { portfolio to spread } \\
\text { risks } \\
\text { Protection against } \\
\text { actions of } \\
\text { competitors }\end{array}$ \\
\hline $\begin{array}{l}2 \text { Resource Seeking } \\
\text { (supply oriented) }\end{array}$ & $\begin{array}{l}\text { Home country - as } \\
\text { above but also market } \\
\text { size \& character } \\
\text { Host country. Availability } \\
\text { of resources, natural, } \\
\text { labour (export process- } \\
\text { ing) technology (eg. } \\
\text { investment by ldcs in } \\
\text { dcs) }\end{array}$ & $\begin{array}{l}\text { As above, but also } \\
\text { privileged access to } \\
\text { markets } \\
\text { Incentives offered } \\
\text { by Government to } \\
\text { fdi (also relevant for } \\
1 \& 3 \text { ) } \\
\text { Oligopolistic market } \\
\text { structure }\end{array}$ & $\begin{array}{l}\text { Avoidance of risks of } \\
\text { breach of contract } \\
\text { and interruption of } \\
\text { supplies } \\
\text { Absence of future } \\
\text { markets } \\
\text { Economics of vertical } \\
\text { integration }\end{array}$ \\
\hline $\begin{array}{l}3 \text { Efficiency Seeking } \\
\text { (rationalised } \\
\text { investment) }\end{array}$ & $\begin{array}{l}\text { VERTICAL } \\
\text { Mainly as } 1 \text { \& } 2 \text { above } \\
\text { HORIZONTAL } \\
\text { Usually distribution of } \\
\text { factor endowments not } \\
\text { very relevant, as inter- }\end{array}$ & $\begin{array}{l}\text { As above but as } \\
\text { investment influ- } \\
\text { enced more by } \\
\text { supply than market } \\
\text { considerations. } \\
\text { Government }\end{array}$ & $\begin{array}{l}\text { As with } 2 \text { above } \\
\text { Economies of scale } \\
\text { and scope } \\
\text { Risk reduction } \\
\text { through product } \\
\text { diversification }\end{array}$ \\
\hline $\begin{aligned} \mathrm{O} & =\begin{array}{l}\text { Ownership } \\
\text { advantages }\end{array} \\
\mathrm{L} & =\begin{array}{l}\text { Locational } \\
\text { advantages }\end{array} \\
\mathrm{I} & =\begin{array}{l}\text { Internalisation } \\
\text { advantages }\end{array} \\
\mathrm{Oa} & =\begin{array}{l}\text { asset } \\
\text { advantages }\end{array} \\
\mathrm{Ot} & =\begin{array}{l}\text { transaction } \\
\text { advantages }\end{array}\end{aligned}$ & $\begin{array}{l}\text { national production in } \\
\text { countries with similar } \\
\text { resource structures } \\
\text { LATERAL } \\
\text { Of limited importance in } \\
\text { effect }\end{array}$ & $\begin{array}{l}\text { imperfections likely } \\
\text { to be of consider- } \\
\text { able importance eg. } \\
\text { tax differentials, } \\
\text { investment incen- } \\
\text { tives, performance } \\
\text { requirements etc. } \\
\text { Note that as above } \\
\text { regional integration } \\
\text { and reduction of } \\
\text { trade barrier aids } \\
\text { rationalised } \\
\text { investment }\end{array}$ & $\begin{array}{l}\text { As above, but in } \\
\text { respect of ancillary } \\
\text { activities eg. various } \\
\text { services - shipping, } \\
\text { consultancy etc. }\end{array}$ \\
\hline
\end{tabular}

\footnotetext{
$\mathrm{O}=$ Ownership advantages

$\mathrm{L}=$ Locational advantages

I = Internalisation advantages

$\mathrm{Oa}=$ asset advantages

$\mathrm{Ot}=$ transaction advantages
} 


\section{Dynamic and Development Aspects of International Production}

Some commentators (e.g., Vernon 1985) have alleged that the eclectic paradigm is couched in static terms and is unable to explain the dynamics or the process of change of international production. Dynamics can be interpreted and modeled in various ways; Vernon's particular concern is that the eclectic paradigm fails to allow for the behavioral interaction between international oligopolists, which both affect and is affected by their foreign activities. In other words, faced with the same set of OLI parameters, not only would the response of MNEs vary according to their strategic postures; but this response might trigger off reactions on the part of their competitors, that themselves may cause a change in one or other of these parameters. In the real world of uncertainty about future markets, the actions of government, the conduct of competitors, suppliers, consumers and labor unions, firms - and particularly those that are geographically or industrially diversified - have a variety of strategic options, simply because they do not know with certainty what is its best option. This is a very different scenario from the one assumed by the neoclassical models, where, once the value of the relevant parameters is known, the first best solution is both identifiable and assumed always to be adopted by MNEs.

The literature identifies various factors likely to influence the strategy of MNEs towards their foreign operations. These include the structure of their existing investment portfolios and risk exposures, their competitive strengths and weaknesses, their bargaining power with governments, their product portfolios, their liquidity position and so on. However, these are at best partial behavioral explanations. The crucial question is whether a general theory of business strategy can be devised that can be used alongside the eclectic paradigm to explain the actions of MNEs in a dynamic situation. Perhaps the best hope for progress here lies in some of the concepts in industrial organization theory, e.g., that of dynamic market contestability ${ }^{30}$ and for the transactional model itself to embrace the type of market failure inherent in interactive behavioral situations.

A somewhat different but nonetheless related interpretation of dynamics might suggest that the eclectic paradigm should embrace the economics of entrepreneurship and technological innovation and change. Mark Casson (1986a) has forcibly argued that any satisfactory explanation of the dynamics of ownership advantage must rest on the reinstatement of the role of the entrepreneur to a central position in the theory of the firm. Like Casson, Cantwell (1986) and Dunning and Cantwell (1986) view the economy as an evolutionary system, and, have applied the eclectic paradigm to analyzing the way in which MNEs both generate and respond to technological change. Economic and business historians, too, are making a useful contribution to our understanding of the growth of international producton, using especially a transaction cost approach (North 1985; Nicholas 1986).

Viewing growth and development from the perspective of countries rather than firms, more progress has been made, using mainly the tools of the development economist. Here, the concept of an investment development path or cycle, as first set out in Dunning (1979), subsequently extended in Dunning (1986c), and modified by Tolentino (1987) is especially relevant. ${ }^{31}$ 
The basic hypothesis of the investment development path or cycle is that a country's propensity to engage in outward direct investment, or be invested in by foreign firms, will vary according to (i) its stage of economic development, (ii) the structure of its factor endowments and markets, (iii) its political and economic systems, and (iv) the nature and extent of market failure in the transaction of intermediate products across national boundaries. It suggests that, as a country's economic development proceeds, its international direct investment position will pass through a number of stages. In the first stage, there will be neither inward nor outward MNE activity, partly because its markets and factor endowments are insufficient to attract either import substituting or resource-based inward investment; and partly, because its political, commercial and technological infrastructure is unable to generate the kind of support services required by foreign direct investors (or, for that matter, by indigenous firms engaged in similar activities). As the infrastructure improves, then, depending on the economic structure of the country and government policy, intermediate products will start to be imported; however, because of the high transaction costs of using external markets, these will tend to be internalized by the foreign suppliers. In this first stage of inward investment, the ownership advantages of MNEs are more likely to derive from the possession of individual intangible assets (Oa) (vis-à-vis those of indigenous firms), rather than on the economies of coordinating multiple activities (Ot); but this will partly depend on whether the MNE already has related investment in other countries and the extent of its intra-firm trade (Dunning 1986c).

The third stage of development is marked by the ability of a developing country's firms to generate their own ownership-specific advantages, which, initially at least, are likely to reflect the structure of the country's factor endowments. Depending on the nature of these advantages, the relative attractions of a foreign location, and their strategic priorities, these firms may go abroad as market or resourceseekers. However, whereas in their early ventures abroad, industrialized countries normally sought natural resources and low cost labor in which their home country was disadvantaged, those from developing countries are currently seeking to acquire technology (i.e., the resource in which they are comparatively poorly endowed). ${ }^{32}$ Alternatively, developing countries may export the kind of intermediate products that require endowments in which they have comparative advantage. In the case of South Korea, Turkey and the Philippines, for example, this has sometimes involved the export of unskilled labor services - notably of construction workers - an intermediate product, traditionally thought to be immobile across frontiers.

It should be noted that the point at which a country reaches the third stage of the investment development cycle - if indeed it is reached at all - rests largely on the structure of its resource endowments, and the attitudes of its government towards international economic involvement in general and inward and outward direct investment in particular. ${ }^{33}$ A country such as India, with its sights set on industrial self-sufficiency, might well prefer to indigenize activities, initially undertaken by foreign affiliates, rather than to participate in an international division of labor in which its own firms become foreign investors. By contrast, economies such as Singapore, Hong Kong, and Taiwan, would seem to favor building up a comparative advantage in the production of intermediate products, that, in part at least, may 
best be used in conjunction with immobile resources in other countries; while, at the same time, they seek to foster inward investment in activities that require immobile resources in which they are evolving (e.g., by way of appropriate education, training and innovating policies) a comparative advantage.

The fourth stage of the investment development cycle occurs when a country becomes a net outward investor. Since by definition the outward capital stock or investment flows of all countries must equal the inward capital stock or investment flows of all countries, it follows that, at a given moment of time, only some countries can be net outward investors. Therefore, any correlation between net outward investment and economic development can only hold good when making crosscountry comparisons. Using time-series data, the correlation may be positive for some countries but not for others. This problem, however, may be overcome by normalizing the per capita income of particular countries by the average per capita for all countries.

But how far can the eclectic paradigm predict which countries will become net outward investors, and/or the point on the investment development cycle that this will occur? And how far can it explain the reduction in the net outward position of some high (and rising) income countries (e.g., the U.S.) in recent years? The answers lie in the changing international distribution of factor endowments, especially those that are transferable across national frontiers; and in the changing efficacy of hierarchies and markets as transnational modes. As a general hypothesis, the less evenly assets (which help produce mobile intermediate products) are distributed across national boundaries, and the greater the transactional failure of markets in these products, the wider will be the dispersion of the net outward investment position of countries ${ }^{34}$ (around a zero net outward investment position). The more evenly resources are distributed, and the less the transactional market failure, the narrower the dispersion in the net outward investment position of countries is likely to be.

The gradual convergence of per capita income levels and the economic structure of the advanced industrialized economies, together with some harmonization of government policies, is making for more symmetrical trans-border direct investment patterns. This phenomena is associated with another, namely the growth of intraindustry production. Like intra-industry trade, such production reflects less the disposition of factor endowments and more the advantages of scale economies in production and marketing, and differences in consumer tastes between countries; although within some sectors (e.g., consumer electronics), there may continue to be some international division of labor based on the distribution of country-specific endowments. ${ }^{35}$ Like inter-industry production, it sometimes replaces trade (e.g., where it is prompted by import restrictions); and sometimes complements or changes the pattern of trade (e.g., where there is specialization of products or production processes in different locations). Again in this latter case, the competitive advantages of the participating firms are less those of the rent-seeking kind, and more those that arise from the common oversight of complementary assets. The fact, too, that intra-industry production is largely in the hands of large and diversified multinational oligopolists adds further to this likelihood. 
The case of Japan is a particularly interesting application of the investment development path, in spite of (or perhaps because of) the fact that government intervention by the Japanese government deliberately curtailed the role of inward investment for most of the second stage of the cycle. In terms of the OLI paradigm, Japan initially disallowed the internalization of most intermediate products (especially technology) markets by foreign MNEs; instead, it acquired these products in other ways, or promoted their indigenous production. This process continued until the Japanese economy had evolved a strong indigenous technological capability, and its firms, distinctive ownership advantages in world markets. At the same time, and partly as a consequence of this process, Japan's locational attractions began to change. Rising real wages reduced the competitive edge of its unit labor costs; technology-intensive and material-saving activities became comparatively more attractive. The net result of these changes was that Japan both needed to export mobile resources and intermediate products to help to relocate the kind of production that required immobile resources in which her comparative advantage was declining, while importing mobile resources and intermediate products that could be used with immobile resources in which her comparative advantage was rising. But for its own firms to become multinational, it also had to accept the presence of foreign MNEs. Moreover, the type of mobile resources it required were not often forthcoming via the non-equity route; in consequence, over the years Japanese policy towards inward direct investment has been liberalized.

In the mid-1980s, Japan entered the fifth stage of development cycle. ${ }^{36}$ This point is reached where two things happen. First the ownership-specific advantages of a country's MNEs become more firm-specific (i.e., of a transaction cost-minimizing kind) and less country-specific (i.e., asset-based); and second, the locational decisions by both foreign and domestic MNEs become less based on the comparative advantage of factor endowments, and more on the strategies of competitors supplying regional or global markets, the desire to fully exploit the economies of large-scale production, the need to reduce market instabilities and uncertainty, and the incentive to reap the gains from integrating related activities over space. To these features another may be added, which rests less on the development stage of a country and more on its economic position vis-à-vis that of other countries. Here, the proposition is that as countries converge in their income levels and economic structures, the more symmetrical cross-investment flows are likely to be. The relatively faster growth of European and Japanese direct investment in the U.S. than of U.S. direct investment in Europe and Japan in the 1970s and the early 1980s lends support to this proposition; while the dramatic improvement of U.S. economic performance in the mid-1980s, the accelerated path of technological advance, and the realities of global competition is causing a resurgence of foreign activity by U.S. MNEs.

The fact that Japanese participation in European and U.S. manufacturing industry is currently growing very quickly, and especially in those sectors (e.g., electronics and motor vehicles) that tend to be dominated by MNEs; and that European and U.S. firms in similar industries are forming alliances with the Japanese in their home markets (Ohmae 1985) suggests that the structure of Japanese outward direct investment is now increasingly resembling that of the U.S. and European 
countries. And, indeed, it may be reasonably predicted that as the Japanese economy becomes an increasingly high-wage and technology-intensive economy, yet more internationally oriented, that the character of Japanese MNEs will change in two ways. First a higher proportion of their investments will be directed to the developed world and be within similar sectors to those invested in by foreign companies in Japan. Second, their competitive strengths will come to depend more on their ability to operate successfully a global network of interrelated activities than on the favored possession of particular assets. At the same time, while there is some suggestion (Dunning 1986a) that Japanese manufacturing MNEs are currently concentrating their high-value activities in their home plants, a need to tap and monitor the latest technological advances in such sectors as biotechnology and telematics is encouraging these same MNEs to set up (or share with local firms) research, development and design facilities in Europe and the U.S. (Ohmae 1985).

\section{Explaining Different Forms of International Economic Involvement}

The third direction in which the eclectic paradigm of international production might be extended is for it to incorporate other forms of international business transactions, notably arms-length trade, joint ventures and non-equity contractual agreements. To date, however, while some progress has been made in embracing the latter two subject areas ${ }^{37}$ - indeed, some authors (e.g., Casson 1986d) would go so far to argue that the contractual relationship, be it part of an equity or non-equity form of busines association, is the key to our understanding of international business involvement - only limited headway has been made in unifying explanations of trade and production. ${ }^{38}$ We suggest there are two main reasons for this. The first is that the modern theory of international production derives its analytical framework from the theories of the firm and industrial organization rather than from the theory of international trade; and, implicitly, at least, all tradeable activities are assumed to be conducted between independent buyers and sellers. ${ }^{39}$ Secondly, while the latter theory takes as its unit of interest the nation state, the focus of interest of students of the MNE is the firm or groups of firms.

It is true that several of the modern theories of trade - particularly those designed to explain intra-industry transactions - explicitly acknowledge the role of market imperfections as determining factors; but the emphasis of interest is strongly directed to structural rather than transactional imperfections (Krugman 1981, 1983). Much of neo-technology and monopolistic competitive trade may be explained by the spatial distribution of resources that gave rise to ownership-specific advantages, but which are used by firms in conjunction with immobile resources located in the home country. When a firm goes abroad, it exports these intangible assets or their rights, and uses them in conjunction with foreign resources that it can obtain at lower cost than at home. However, the implications of transactional market failure that make for the common ownership of assets across national boundaries, and which, in turn, may impinge on the trading competitiveness of firms, have been largely neglected by trade theorists. It is here that an integrated approach to production and trade offers particular promise (Dunning and Norman 1985). 
Historically, there are many parallels in the way in which the patterns of trade and international production have evolved. To start with, most trade was intersectoral and largely explainable by the international distribution of factor endowments. Likewise, as we have already suggested, although an element of market failure is necessary to explain the ownership of international production, its structure and location initially follow the dictates of the H-O-S paradigm as applied to intermediate products. Later as trade became more intrasectoral, new explanations were sought and found (Grubel and Lloyd 1975, Tharakan 1984). Intrasectoral production also possesses many of the attributes of intra-industry trade, but with additional market imperfections (notably those which are unique to the common ownership of assets in different countries and the internalization of trade in intermediate products). Moreover, unlike intra-industry trade, intra-industry production implies intra-firm trade as well. Indeed, the ability of a firm to trade internally may itself afford that firm certain advantages over its competitors (e.g., the possibility of gains from specialized sourcing or transfer price manipulation). It is, then, not surprising that the more multinational a firm becomes, the more it is inclined to engage in internalized trade (Dunning and Pearce, 1985).

The economic theory of intra-firm trade, and how it differs from inter-firm trade is now beginning to receive some attention in the literature; but again, mostly by scholars interested in the organization of transactions rather than the transactions per se. Normatively, insofar as intra-firm trade is market replacing, it has been viewed with some suspicion by welfare economists, and is commonly perceived as a means through which MNEs manipulate transfer prices in a way inimical to the interests to one or other (or both) of the trading countries. Though the organization of trade need not affect its extent, pattern, or terms, the countryspecific differences in the perceived gains which transfer pricing manipulation may encourage MNEs to locate production in countries in which the gains are thought to be most likely. On the other hand, MNEs may engage in intra-firm international trade for exactly the same reason as domestic firms may engage in intra-firm national trade, namely, to internalize the external economies of individual transactions. Whether this benefits or adversely affects the distribution of international economic activity and/or the welfare of the participating countries, depends on the nature of the market failure being internalized, the consequences of such internalization, and how the gains or losses resulting from it are distributed. But there is no a priori reason to suppose that intra-firm trade in final goods products is less beneficial to international resource allocation than either inter-firm trade conducted in imperfectly competitive markets or intra-firm trade in intermediate products.

The fact that an optimum solution (in the Pareto sense) is so difficult to identify is that, because market failure exists, one is forced to compare a number of second best alternatives. Once matters such as the distribution of benefits over time, risk and government intervention enter the equation, one's criteria for judging optimality inevitably becomes multifaceted. While in principle, transactions between different parts of a domestic firm pose identical problems, the gains or losses resulting from the transactions are at least contained in that country. In the case of trade within hierarchies across national boundaries, inter-country distributional questions cannot 
be ignored; just as governments may judge internal allocative efficiency in terms of their own economic and social goals, so they will evaluate the impact of MNEs on the extent and pattern of trade flows.

Before concluding this section, brief reference may be made to one of the fastest growing forms of institutional arrangements, namely, the cross-border non-equity collaborative venture at a product or project level between MNEs, and particularly those operating in the OECD area. These have arisen for a variety of economic and strategic reasons, but as several contributors to a recent symposium on the subject (Contractor and Lorange 1987) demonstrated, the exploitation of complementary ownership advantages by horizontal or vertical integration, is not only consistent with the premises of the eclectic paradigm, but points to a need for broadening its scope to embrace quite specific, and perhaps temporary, international alliances between enterprises, as part and parcel of their wider international strategies.

\section{The Locus of Decision-taking}

One subject area, normally considered outside the domain of the economist but one in which we believe the eclectic paradigm offers a useful conceptual framework, concerns the geographical locus of decision-taking within the MNE. Let us focus on the question, Why and under what conditions are decisions on the way in which resources are allocated by foreign affiliates of MNEs controlled or influenced by managers ${ }^{40}$ located in the parent company? This question may be broken down into the "where" and "who" aspects of decision-taking. The former is mainly an issue of locational economics, and concerns the price and efficiency of decisiontaking (including support) resources in different countries, and the costs of transborder inter- and intra-firm transactions (e.g., especially administration and communication costs), in which managers are involved. Here a factor endowment model may be the appropriate tool of analysis.

The "who" aspect may be divided into two components that parallel two questions asked earlier in this paper: Why does a MNE undertake production in a foreign country rather than an indigenous firm in that country?, and, Why does a MNE choose to internalize the market for the cross-border transfer of intermediate products? The competitive advantage of centralized decision-taking rests in the capacity to take (what are perceived to be) the right decisions for the MNE as a whole. If, for one reason or another, such capacity cannot be efficiently transferred to foreign affiliates - either through the training of local managers or by exporting expatriates - then the decision-taking resources will be located in the home country. Clearly, the more the specificity, idiosyncrasy, or non-codifiable nature of information and related managerial assets, the more difficult it is to ensure an efficient use of them in a foreign affiliate. And the greater the advantages of scale economies or benefits of centralized decision-taking, that accrue to the MNE in toto then the less likely decision-taking is to be delegated. On the other hand, the more decisions required to be customized to local needs, or depend on indigenous support facilities and expertise for their efficient execution (e.g., with respect to personnel management, industrial relations, distribution and public relations), the more likely they are to be decentralized. 
But even assuming there is capacity in the host country to assimilate the transfer of ownership-specific advantages, unless there is a mutuality of interests between managers at headquarters and their agents in the affiliates, decision-taking may still be centralized. When might this occur? Two possibilities arise. The first is wherever, as a consequence of the actions of an affiliate, there are costs and benefits that accrue to the rest of the organization of which it is part; and the second is where there is a different perception of objectives and/or risks by local and central management. Take a simple example. Suppose a MNE operates two manufacturing plants, one in the U.S. and the other in France. Assume the aim of each is to maximize local profits, and that each acts as an independent decisiontaking unit. Then as long as the locational advantages favor the siting of managerial resources in France, and these resources are efficiently used, decisions will be decentralized. Now suppose the parent plant adopts a new strategy aimed at maximizing group profits. To do so it may need (and the situation is comparable to a takeover by one firm of another) to centralize decisions so as to both rationalize resource allocation and capture any benefits external to either of the production units but internal to the organization as a whole. In this way, by centralizing decisiontaking, the MNE is undergoing an hierarchical process very similar to that of the internalization of intermediate product markets.

Using the OLI framework, then, it may be possible to construct an economic theory of the locus of decision-taking (and as a variant of this, within a location, the nationality of the decision taker). ${ }^{41}$ The hypothesis is that decision-taking will be more centralized: (i) the greater the uniqueness, specificity and non-codifiable nature of decision-taking advantages emanating from the home country; (ii) the greater the likelihood of a conflict of interests between the parent company and the subsidiary, with respect especially to (a) risk perception and (b) externalities; and (iii) the more the locational costs of decision-taking resources favors the home country, which might reflect both difficulties in transferring management attitudes and practices, and the price of management and management-related services.

These elements will clearly vary according to country industry and firm-specific factors, and also according to the decision-taking functions. The tendency to centralize decisions relating to research and development, capital budgeting and accounting methods, but to decentralize those relating to personnel matters and sourcing arrangements, might be explained in these terms. Some illustrations of the use of this approach is contained in Dunning (1986b), which examines the locus of decision-taking as between U.S. parent companies and their U.K. subsidiaries in the 1950s and their Japanese counterparts in the 1980s. ${ }^{42}$

\section{Divestment by MNES}

A fifth possible area for further study relates to our understanding of divestment or a reduction of foreign production by MNEs. Some progress along these lines has been made by Boddewyn (1983) and Casson (1986d), but by and large, the literature has so far treated divestment as a discrete act of asset disposal (i.e., the reverse of acquisition) rather than part and parcel of a continual reappraisal of the amount and disposition of the assets a firm wishes to hold. The process of a reduction, or disintegration of foreign production, is different from an initial 
act of entry in two ways. First, it requires the absence of only one of the three OLI variables; and second, there may be certain barriers to exit that do not correspond to barriers to entry. ${ }^{43}$

Using the "Mark 2" version of the eclectic paradigm set out earlier in this paper, we might predict that MNEs would wish to reduce their presence in a particular country or sector under two circumstances. First, where a change in the distribution of factor endowments (or the efficiency with which these are used) (i) weakens their competitive advantages, relative to those of firms in host countries, or (ii) causes them to switch production from the host to home (or indeed, other host countries). ${ }^{44}$ Second, where the net transactional benefits (costs) or using the external markets for the exploitation of these competitive advantages increase (fall) relative to those offered administered hierarchies. ${ }^{45}$

As a starting point for an integrated approach to an understanding of changes in international production, let us assume that once a firm is established abroad, its sequential investment decisions are organically related to the size and pattern of its existing investments, and to its views about (a) its existing and likely future competitive strengths and weaknesses, (b) its expectations about technological and market opportunities, and (c) its perception of its competitors' reactions to (a) and (b). In a dynamic situation, this is likely to result in a continual reassessment, relocation and reorganization of activities. As a firm's competitive position changes; as new core skills replace existing ones; as new management strategies evolve; as new markets open up and others die; and as the balance of advantage between using internal and external markets shifts, so will the level and structure of its international production. Although in some cases, this may lead to a divestment of the entire foreign assets of a firm, more often, it will result in a restructuring of its portfolio, with a sale of assets in some countries or sectors helping to finance an increase of assets in others. Integration and disintegration within MNEs often go hand in hand with each other, just as do the birth and death of firms. ${ }^{46}$

The realignment of the OLI advantages of leading international investors in the last two decades provides ample confirmation of the relevance of the factor endowment model component of the eclectic paradigm. The emergence of Japan as a significant international investor has resulted in a fall of the share of U.S. and European MNEs in several industrial sectors, notably automobiles and consumer electronics. The growth of offshore manufacturing in some developing countries in the 1970s to take advantage of an apparently changing international division of labor helped accelerate the decline of labor-intensive domestic sectors (both of multinational and uninational companies) in developed countries. However, recent technological advances, while placing a premium on skilled labor, have at the same time reduced the significance of labor costs in many manufacturing processes. This has resulted in a return home of some of these activities. ${ }^{47}$ Within some of the more rapidly developing idustrializing developing countries (e.g., South Korea, Taiwan and Singapore), one has also seen divestment in low value-added and new investment in high value-added activities. In some primary sectors, mainly at the insistence of host governments, one has witnessed a marked decline in inward investment; in others, and particularly in some service industries, domestic and/ 
or international vertical integration has sharply increased. Just as the volume and pattern of trade of a firm or country is affected by changes in the distribution of factor endowments, so will that of international production.

The question of the changing ownership of assets in particular countries is perhaps more interesting. Why should MNEs sell assets and acquire others? Clearly, when there are changes in the relative transaction costs of individual capital and foreign exchange markets (not least due to uncertainties about interest and exchange rates), MNEs will reappraise their international financial portfolios. But what about longterm real forces? The answer must be that, where incentives for the direct investment are reduced or advantages of common governance disappear, so divestment will occur, providing that the exit costs (which themselves involve transaction costs) do not outweigh the savings of using the market. The transaction costs of exit require further study, but anything that reduces the risk and uncertainty of external markets, lessens the importance of scale economies in production, or reduces the externalities of particular transactions will make for divestment. ${ }^{48}$

This shifting of the balance of advantages of hierarchies and external markets for international transactions, together with the emergence of new contractual arrangements which possess some of the characteristics of each (Oman 1984, Casson 1986c), has led to frequent realignments of the functions and boundaries of MNEs. While vertical integration has noticeably increased in some sectors (e.g., vehicles and electronics) and fallen in others (e.g., hotels and shipping), ${ }^{49}$ the general trend has been towards new collaborative arrangements built around a group of core technologies. This has elsewhere been termed quasi-integration (Contractor and Lorange 1987). At the same time, technological and organizational advances have increasingly linked investment in services with investment in goods; the information industry is a classic example. In secondary industry, new alliances between firms along the value-added chain have been fostered, to exploit complementary technologies and to link computer-aided design of components with that of later manufacturing processes (Hayes and Wheelright 1984). On the other hand, the sizeable amounts of capital involved and the danger of an integrated firm being locked into one particular source of supply increases the risk of internalization..$^{50}$

Similarly, the raison d'etre of horizontal integration may change as the importance of synergistic ownership advantages shifts with advances in technology and information. The extent of cross-hauling of hierarchical or quasi-hierarchical arrangements in the technologically advanced sectors between the U.S. and Japan is testimony of this. Indeed the growth of global industries, characterized by a substantial amount of intra-industry and intra-firm production and an interlocking network of cross-border alliances is a feature that industrial organization economists and strategists are only just starting to get to grips with. But here too, an organic approach to both divestment and investment by MNEs is required.

\section{The Consequences of MNE Activity}

One final area in which the eclectic paradigm can be a useful framework for analysis is in examining the impact of MNE activity on home and host country economic goals. Let us illustrate from the viewpoint of a host country. 
The argument runs something like this. Inward direct investment is welcomed for the resources and/or access to markets it brings to the recipient country, and the way it may promote the upgrading and better deployment of existing indigenous endowments. The concern over this particular vehicle of importing intermediate products is two-fold. First, that because of its strong bargaining power, the investing firm is able to capture an undesirably high share of the value added or created by its subsidiary in the host country; and second, that decisions taken about the amount and kind of resources transferred, and about the use of these resources, may yield less benefit to the recipient country than that which might arise from some other pattern of resource allocation.

In the one case, the MNE is regarded as an organizational mechanism by which intermediate products, which are unavailable or costly to produce in the host country, are efficiently acquired and used; in the other, as a vehicle of economic rationalization and economic power, which it uses to promote its global goals in a way which distorts or inhibits the desired disposition of resources by the host country.

The debate over the impact of inward direct investment on host countries is now entering a new phase as markets and production become increasingly internationalized. Moreover, not only are MNEs taking a global view of their strategies - and view the locational attributes of countries from this perspective - but countries also are beginning to recognize that their industrial strategies and competitive postures must take on an international dimension. Since the industries which most countries view as strategically desirable are largely dominated by MNEs, it follows that conflict between multinational oligopolies pursuing global economic strategies and countries pursuing domestic political strategies - and both within a changing and increasingly competitive international environment - is inevitable, and, in part, irreconcilable. In the 1950s and '60s, the interest centered largely on whether the types of resources provided by MNEs were appropriate to needs of recipient countries; and if, compared with alternative routes of acquiring these resources, their benefits exceeded their costs. The debate in the 1980s has much more to do with the way in which MNEs use their worldwide assets to achieve their longterm economic goals; and whether the resulting allocation of activity is consistent with that which the countries in which they operate are seeking to achieve. As a framework for analyzing these questions, we believe that the eclectic paradigm has a great deal to offer.

\section{CONCLUSIONS}

This paper has sought to demonstrate that, a decade after its inception, the eclectic paradigm remains a useful and robust general framework for explaining and analyzing not only the economic rationale of international production but many organizational and impact issues relating to MNE activity as well. Conceptually, there are close parallels between the main tenets of the paradigm and that of modern theory of business strategy; ${ }^{51}$ though neither approach is sufficient to explain the international profile of any particular MNE. It is likely, however, that new theorizing in the next decade will take a different form to that of the last ten years, if for no other reason than the character and organization of international production is itself undergoing fundamental change. More especially, we foresee a more systematic 
effort by trade economists to model transactional market failure into more general theories of international economic involvement, while industrial and business economists are likely to become more interested in the dynamics of the OLI configuration, and its impact on the strategy of individual firms, through such techniques as game theoretic analysis and network models (Johanson and Mattson 1987). We expect more attention to be paid to the determinants and effects of collaborative ventures now being formed between MNEs from advanced countries (Contrator and Lorange 1987), and between MNEs and their customers and suppliers.

We foresee a renewed interest in identifying and evaluating the ownership-specific advantages of firms, with particular focus on entrepreneurship, the ability of management to identify and coordinate a range of core skills and assets through a variety of organizational routes, and to promote operational flexibility in a volatile world environment; global marketing networks; the creation and use made of computer-related information and communications technology; and a variety of cross-cultural management-related issues. Finally, we would perceive a gradual interweaving of the approaches of the economist, business analyst and organizational theorist to our understanding of international production, although within these and related disciplines, theorizing and empirical work will become both more technically sophisticated and more policy oriented.

\section{NOTES}

1. Defined as production financed by foreign direct investment and undertaken by multinational enterprises.

2. The proceeds of which were published under the editorship of Ohlin et al. (1977).

3. But see our remarks in the second section of this paper.

4. For a recent review of the literature on intra-industry trade, see Tharakan (1984).

5. For an elaboration of this thesis see Dunning and Norman (1985).

6. A full account of the eclectic paradigm is given in Dunning (1981). See also Dunning (1983a and 1986d), Dunning and McQueen (1981), Dunning and Norman (1985), and Norman, Flanagan and Seymour (1985) for some extensions and applications of the concept.

7. Dunning (1981) page 27.

8. Teece (1983) uses a rather different terminology, namely production and transaction advantages.

9. For example, as identified by Bain (1956) as monopoly power, product differentiation, absolute cost barriers and government intervention.

10. See, for example, an interesting paper by Buckley (1986) presented to the London meeting of the Academy of International Business in November 1986.

11. See especially Casson (1979), Buckley and Casson (1985), Teece (1981) and (1985), Hennart (1986), and Rugman (1986). The word "failure" is an unfortunate one as it implies that there is an alternative transactional mechanism which is superior to the market. This is not necessarily the case.

12. As, for example, occurs in the case of "natural monopolies" and in industries with high sunk or developmental costs.

13. For example, in the U.K., Japanese affiliates dominate the color TV sector partly because their parent companies prefer this route of entry rather than licensing their competitive advantages to U.K. producers; but partly too, because they are more successful at internalizing intermediate product transactions, than, for example are their U.S. counterparts.

14. In that what might be (or was) exogenous the firm is (or now becomes) endogenous.

15. We would also accept with Hennart $(1982,1986)$ that a privileged access to technology or capital may enable a firm to internalize cross-border intermediate product markets. We would, however, suggest that the privileged access per se arises because of an operational rather than an organizational failure of that market, in the sense that it discriminates in favor of particular groups of transactors, rather than it fails as a transactional mode, c.f. some other mode, e.g., a firm. 
16. For a useful distinction between transferable and nontransferable intermediate products, see Lall (1980).

17. It is possible for government intervention to be directed to counteracting or alleviating the affects of market failure as well as distorting the pattern of resource allocation to meet its social and strategic goals. See especially page 113, Table 5.2 in Dunning (1981).

18. The concept of 'induced' or 'managed' comparative advantage is gaining strength in the literature. (See for example Scott and Lodge 1985, Teece 1987.) It suggests that, at a given moment of time, a country's productive assets consist not only of the natural resources then available (defined in the H-O-S sense) but the accumulated manmade assets of the past; the way in which these are organized; and the attitudes of its people towards wealth creation and economic security, and towards the rest of the world. The literature further suggests that government may and does play a major role in fashioning the strategy for resource allocation and income distribution; the transaction costs of markets; and of the ideological, cultural and work ethic of its population.

19. Sometimes referred to as the environment, systems and policy (ESP) paradigm. See Koopman and Montias (1971) and Dunning (1981). See also a paper by Boddewyn (1986).

20. See, for example, Robock and Simmonds (1983) and Rugman, Lecraw and Booth (1985).

21. See particularly Porter (1985) and (1986), Hamel and Prahalad (1987) Lahdepaa and Ansoff (1987). The difference between the firm-specific variables identified by these scholars and those of their predecessors is that the latter concentrated on the structural characteristics of firms, e.g., size, age, product composition, etc., while the former focused on operational, i.e., strategic-related characteristics, such as those identified by above.

22. It is one of the more irritating characteristics of academic researchers (and the present author is no exception!) for them to invent their own nomenclature for concepts that are familiar under different names to other researchers. Thus Porter's concept of configuration is for all intents and purposes the same as our location advantages; while his coordination dimension is similar to those aspects of internalization that relate to the common governance of value-adding activities. Finally Porter's competitive advantages make up a major part of our concept of ownership advantages. The only difference, as far as I can see, is that our concept of ownership advantages may include attributes of firms that more accurately reflect their monopolistic power than their competitive prowess.

23. Some of these were identified by the author when Aliber's thesis (Aliber (1970) was first put forward (Dunning (1971)). See also more recent criticisms by Gray (1982) and Teece (1986).

24. For a more extended analysis of the differences and similarities between the Kojima and the eclectic and internalization paradigm, see Buckley (1983) and (1985) and Gray (1985).

25. Unless the asset is sold outright in the first place.

26. This suggests that economists interested in explaining the international allocation of activity both by firms and countries needed to be versed in modern trade and location theory, industrial organization theory and the theory of the firm, and on the way in which each interacts with the other. Both Casson (1985a), and Norman and Dunning (1984) take up and illustrate this point. See also page 27-31 of this paper.

27. See Kogut (1983). At the same time, the extent and pattern of market failure may itself be country-specific. Compare, for example, the organizational structures and sub-contracting relationships of U.S. and Japanese firms (Imai 1985; Sullivan and Nonaka 1986).

28. A first attempt to do this by use of cluster analysis was made in Chapter 5 of Dunning (1981).

29. For example, while it may be possible to identify the major variables influencing all import substitution FDI, there may be additional factors specific to (say) Swedish investment in the Thai car industry.

30. See, for example, some work on these lines by Graham (1986) and Johanson and Mattson (1987).

31. For a full explanation, see Chapter 5 of Dunning (1981 and 1986c). The term "cycle" was used in that it was predicated that a country both started as a zero net outward and, at a later stage in its development, returned to that position when its inward direct investment stake was balanced by its (growing) outward direct investment stake. In retrospect, the term "path" might have been a better word to describe the process of change in a country's international direct investment position.

32. Hence the acquisition or part acquisition of European and U.S. high technology firms (particularly those in difficult financial straits) by, e.g., Indian, Middle Eastern, and Chinese firms.

33. The role of government is one of the most idiosyncratic to evaluate. In the ' $70 \mathrm{~s}$ and ' $80 \mathrm{~s}$, for example, there have been quite dramatic swings in the policies of individual countries to inward investment, according to the government in power. Insofar as it is possible to generalize, the more right (left) wing a government is in relation to its predecessor, the more (less) liberal its attitude is likely to be towards inward and outward foreign direct investment and indeed to private enterprise as a whole. 
34. Most countries are in fact negative net outward investors, i.e., net inward investors.

35. For example, MNEs may continue to concentrate their high-value (e.g., research and development) activities in countries that have a comparative advantage in the supply of highly trained manpower, while locating the low-value-added activities in countries that have a comparative advantage in the supply of low- or semiskilled labor.

36. Not considered in the original version of the theory. For an elaboration see Dunning (1986c).

37. For a review of the literature see Oman (1984) and Buckley and Casson (1985).

38. With some noticeable exceptions, e.g., the work of Hirsch (1976), Gray (1982), Ethier (1986) and Markusen (1986).

39. And no distinction appears to be made between multi-activity and single-activity trading firms.

40. Using managers as a generic term for decision takers.

41. For example, why are most Japanese manufacturing subsidiaries in the U.K. headed by a Japanese expatriate whereas most U.S. subsidiaries have a U.K. national as chief executive?

42. See also some interesting work on the structure of decision-taking in U.K. subsidiaries in the 1970 s by Young, Hood and Hamill (1985).

43. Porter (1980) identifies six of these, namely the presence of specialized assets, fixed costs, strategic exit barriers, information constraints, managerial emotions and pride, and government-related barriers.

42. The question of a reduction in foreign production in toto and that in a particular country and/or sector needs more careful distinction than it has been given up to now.

45. We use the term net benefits and costs because there are often costs and benefits of using both routes for transacting goods and services.

46. It is interesting that there is abundant literature on the theory of the growth of the firm (which, in practice, often occurs as a result of the expansion of part of a firm's activities), but very little on the decline of the firm. Yet, particularly in times of rapid technological change, growth and decline are handmaidens to each other.

47. Ohmae (1985) suggests that while labor costs in many developing countries are only one-third of those in developed countries, the direct labor costs in the major competitive manufacturing companies represent less than $10 \%$ of total costs. The savings on costs in producing in developing countries is often more than outweighed by the transport costs between developing and developed countries. Moreover, as real wage costs rise in developing countries, these savings are likely to fall.

48. It is worth emphasizing at this point that internalization is not without its costs and multinationality may bring diseconomies, external to particular affiliates and internal to the MNE.

49. See Dunning and McQueen (1981) and Casson (1986b). In both these latter cases, contractual agreements of one kind or another have enabled the contractor to gain many of the benefits of integration without the costs.

50. For a summary of some interesting work on the integration of information systems in manufacturing see DeMeyer and Ferdows (1984). For a general view of changing corporate strategies in a time of technological change, see Ergas (1985) and Dunning (1986c).

51. As, for example, set out by Porter (1980, 1985 and 1986) and Kogut (1985a). The expression "competitive advantage" may be interpreted as ownership-specific advantage, while the comparative advantage of countries appears synonymous with our location advantage. While the business strategy approach gives more emphasis to the positioning of firms in the sectors in which they compete, the eclectic paradigm places more stress on the organizational form of transactional relationships.

\section{REFERENCES}

Aliber, R. 1970. A theory of foreign direct investment. In C.P. Kindleberger, The international corporation. Cambridge: MIT Press.

1983. Money, multinationals and sovereigns. In C.P. Kindlberger and D.B. Audresch, The multinational corporation in the 1980s. Cambridge: MIT Press.

Bain, J.S. 1956. Barriers to new competition. Cambridge, Mass.: Harvard University Press.

Boddewyn, J. 1983. Foreign divestment theory: Is it the reverse of FDI theory? Weltwirtschaftliches Archiv, 119:345-55. 
1986. International political strategy: A fourth 'generic' strategy? Paper presented to the Academy of International Business Annual Meeting, London, November 1986.

Buckley, P.J. 1983. Macroeconomic versus international business approach to direct foreign investment: A comment on professor Kojima's interpretation. Hitosubashi Journal of Economics, 24:95-100.

1985. The economic analysis of the multinational enterprise: Reading v. Japan. Hitosubashi Journal of Economics, 26:117-124.

1986. The limits of explanation: Tests of the theory of the multinational enterprise. Paper presented to Academy of International Business Annual Meeting, London, November 1986.

Cantwell, J.A. 1986. Technological innovation and international production in the industrial world: $A$ study of the accumulation of capital in international networks. Ph.D. thesis, University of Reading, 1986.

Casson, M.C. 1979. Alternatives to the multinational enterprise. London: Macmillan.

1985. The theory of foreign direct investment. In P.J. Buckley \& M.C. Casson, The economic theory of the multinational enterprise. London: Macmillan.

1986a. General theories of the multinational enterprise: A critical examination. In P. Hertner \& G. Jones, eds., Multinationals: Theory and history. Aldershot \& Brookfield, Vt.: Gower.

1986b. The role of vertical integration in the shipping industry. Journal of Transport Economics and Policy, 22 (January):7-29.

1986c. Alternative contractual arrangements for technology transfer: New evidence from business history. University of Reading, Discussion Papers in International Investment and Business Studies No. 95 (May).

. 1986d. Foreign divestment and international rationalization: The sale of Chrysler (UK) to Peugot.

In J. Coyne \& N. Wright, eds., Divestment and strategic change. Oxford: Philip Allan.

1987. The firm and the market. Oxford: Basil Blackwell.

Coase, R.H. 1937. The nature of the firm. Economica, 4 (November):386-405.

Contractor F. \& P. Lorange. 1987. Cooperative strategies in international business. Lexington, Mass.: Lexington Books.

Davidson, W.D. 1976. Patterns of factor saving innovation in the industrialized world. European Economic Review, 8:207-17.

\& D.G. McFeteridge. 1984. International technology transaction and theory of the firm. Journal of Industrial Economics, 32:253-64.

1985. Key characteristics in the choice of international transfer mode. Journal of International Business Studies, 16 (Summer).

DeMeyer, A. \& K. Ferdows. 1984. Integration of information systems in manufacturing. INSEAD Research Working Papers No. 13, December.

Dunning, J.H., ed. 1971. The multinational enterprise. London: Allen \& Unwin.

1981. International production and the multinational enterprise. London: Allen \& Unwin.

1982. International business in a changing world environment. Banco Nazionale del Lavoro Quarterly Review, 143:351-373.

. 1983a. Changes in the structure of international production: The last 100 years. In M.C. Casson, ed., The growth of international business. London: Allen \& Unwin.

1983b. Market power of the firm and international transfer of technology. International Journal of Industrial Organisation, 1:333-351.

1986a. Japanese participation in British industry. London: Croom Helm.

1986b. Decision-making structures in US and Japanese manufacturing affiliates in the UK: Some similarities and contrasts. Geneva: ILO Working Paper No. 41.

.1986c. The investment development cycle and third world multinationals. In K.M. Khan, ed., Multinationals of the south. London: Francis Porter.

. 1987a. International business and economic restructuring. In N. Hood \& J.E. Vahlne, eds., Strategies in global competition. London: Croom Helm.

. 1987b. Cross-border corporation integration and regional integration. University of Reading Discussion Papers in International Investment and Business Studies No. 105, July.

\& J. Cantwell. 1986. The changing role of multinational enterprises in the international creation, transfer and diffusion of technology. University of Reading Discussion Papers in International Investment and Business Studies No. 101, December. 
\& M. McQueen. 1981. The eclectic theory of international production: A case study of the international hotel industry. Managerial and Decision Economics, 2 (December):197-210.

\& R.D. Pearce. 1985. The world's largest industrial enterprises 1962-83. Aldershot: Graver.

\& G. Norman. 1985. Intra-industry production as a form of international economic involvement. In A. Erdilek, ed., Multinationals as mutual invaders. London: Croom Helm.

\& A. Rugman. 1985. The influence of Hymer's dissertation on theories of foreign direct investment. American Economic Review, May:228-32.

Ergas, H. 1984. Why do some countries innovate more than others? Brussels: Center for European Policy Studies. 1985. Corporate strategies in transition. In A. Jacquemin, Industrial policy and international trade. London: Cambridge University Press.

Ethier, W.J. 1986. The multinational firm. Quarterly Journal of Economics, 101:805-833.

Franko, L. 1976. The European multinationals. New York: Harper.

Graham, E.M. 1978. Transatlantic investment by multinational firms: A rivalistic phenomenon. Journal of Post Keynesian Economics, 1 (Fall).

. 1985. Intra-industry direct investment, market structure, firm rivalry and technological performance. In A. Erdilek, ed., Multinationals as mutual invaders. London, Croom Helm.

1986. Internal economies, oligopoly reaction and dynamic contestability in global industries: A first cut at synthesis. Mimeo.

Gray, H.P. 1982. Towards a unified theory of international trade, international production and direct foreign investment. In J. Black \& J.H. Dunning, eds., International capital movements. London: MacMillan.

1985. Multinational corporations and global welfare: An extension of Kojima and Ozawa. Hitosubashi Journal of Economics, 26 (December):125-132.

Grosse, R.R. 1985. An imperfect competition theory of the MNE. Journal of International Business Studies, 16 (Spring):57-80.

Grubel, H.G. \& P.J. Lloyd. 1975. Intra-industry trade, the theory and measurement of international trade in differentiated products. London: MacMillan.

Guisinger, S. 1985. Investment incentives and performance requirements. New York: Praeger.

Hamel, G. \& C.K. Prahalad. 1987. Creating global strategic capability. In N. Hood and J.E. Vahne, eds., Strategies in global competition. London: Croom Helm.

Hayes, R.H. \& S.C. Wheelwright. Restoring our competitive edge: Competing through manufacturing. Chichester \& New York: John Wiley.

Helpman, E. 1984. A simple theory of international trade with multinational corporations. Journal of Political Economy, 92:451-47.

Hennart, J.F. 1982. A theory of multinational enterprise. Ann Arbor: University of Michigan Press.

1986. What is internalization? Weltwirtschaftliches Archiv, 122: 791-804.

Hertner, P. \& G. Jones. 1986. Multinationals: Theory and history. Aldershot \& Brookfield, Vt.: Gower.

Hirsch, S. 1976. An international trade and investment theory of the firm. Oxford Economic Papers, 28:25870.

Horst, T.O. 1972. Firm and industry determinants of the decision to invest abroad. Review of Economics and Statistics, 54 (August).

Horstman, I. \& J.R. Markusen. 1986. Licensing v direct investment: A model of internalization by the multinational enterprise. University of Western Ontario, mimeo.

Hymer, S. 1960. The international operations of national firms: A study of direct investment. Ph.D. thesis, MIT (published by MIT Press under the same title in 1976).

Imai, K. 1985. Network organization and incremental innovation in Japan. Institute of Business Research, Hitotubashi University. Discussion Paper No. 122, July.

Johanson J. \& L.G. Mattsson. 1987. Internationalization in industrial systems - A network approach. In N. Hood \& J.E. Vahne, ed., Strategies in global competition. London: Croom Helm.

Knickerbocker, F.T. 1973. Oligopolistic reaction and the multinational enterprise. Cambridge, Mass.: Harvard University Press.

Kogut, B. 1983. Foreign direct investment as a sequential process. In C.P. Kindleberger \& D. Audretsch, eds., The multinational corporation in the 1980s. Cambridge: MIT Press. 
. 1985a. Designing global strategies: Corporate and competitive value added chain. Sloan Management

Review, 25 (Summer):15-28.

. 1985b. Designing global strategies: Profiting from operational flexibility. Sloan Management Review, 26 (Fall):27-38.

Kojima, K. 1978. Direct foreign investment. London: Croom Helm.

1982. Macroeconomic versus international business approach to foreign direct investment. Hitosubashi Journal of Economics, 23:1-19.

\& T. Ozawa. 1984. Micro and macro-economic models of direct foreign investment: Towards a synthesis. Hitosubashi Journal of Economics, 25 (2):1-20.

1985. Towards a theory of industrial restructuring and dynamic comparative advantage. Hitosubashi Journal of Economics, 26 (December):135-145.

Koopman, K \& J.M. Montias. 1971. On the description and comparison of economic systems. In A. Eckstein, Comparison of economic systems. California: University of California Press.

Krugman, P.M. 1981. Intra-industry specialization and the gains from trade. Journal of Political Economy, 89.

1983. The new theories of international trade and the multinational enterprise. In C.P. Kindleberger \& D. Audretsch, eds., The multinational corporation in the 1980s. Cambridge: MIT Press.

Lahdepaa, J. \& K. Ansoff. 1987. A network analysis of international transactions. In N. Hood \& J.E. Vahne, eds., Strategies in global competition. London: Croom Helm.

Lake, A.W. 1976a. Transnational activity and market entry in the semi-conductor industry. NBER Working Paper 126, March.

. 1976b. Foreign competition and UK pharmaceutical industry. NBER Working Paper 127, March.

Lall, S. 1980. Monopolistic advantages and foreign involvement by US manufacturing industry. Oxford Economic Papers, 32:102-122.

Markusen, J.R. 1984. Multinationals, multi-plant economies and the gain from trade. Journal of International Economics, 16:205-216.

Mason, R.H. 1980. A comment on professor Kojima's Japanese type versus American type of technology transfer. Hitosubashi Journal of Economics, 20:242-52.

Nicholas, S. 1986. The theory of multinational enterprise as a transactional mode. In P. Hertner \& G. Jones, eds., Multinationals: Theory and history. Aldershot: Gower.

Norman, G., R. Flanagan, \& H. Seymour. 1985. A theory of international production in the international construction industry. University of Reading Discussion Papers in International Investment and Business Studies No. 87.

\& J.H. Dunning. 1985. Intra-industry foreign direct investment: Its rationale and trade effects. Weltwirtschaftliches Archiv, 120:522-540.

North, D.C. 1985. Transaction costs in history. Journal of European Economic History, 14:557-574.

Ohlin, B., P.O. Hesselborn \& P.M. Wiskman, eds. 1977. The international allocation of economic activity. London: MacMillan.

Ohmae, K. 1985. Triad power. New York: The Free Press.

Oman, C. 1984. New forms of international investment in developing countries. Paris: OECD.

Pavitt, K. 1987. International patterns of technological accumulation. In N. Hood \& J.E. Vahne, eds., Strategies in global competition. London: Croom Helm.

Porter, M.E. 1980. Competitive strategy. New York: The Free Press.

1985. Competitive advantage. New York: The Free Press.

, ed. 1986. Competition in global industries. Boston: Harvard Business School Press.

Pralahad, C.K. \& Y.L. Doz. 1987. Quality of management: An emerging source of global competitive advantage. In N. Hood \& J.E. Vahne, eds., Strategies in global competition. London: Croom Helm.

Robock, S.F. \& K. Simmonds. 1983. International business and the multinational enterprise, third edition. Homewood: R.D. Irwin.

Rugman, A.M. 1979. International diversification and the multinational enterprise. Farnborough: Lexington.

. 1981. Inside the multinationals: The economics of internal markets. London: Croom Helm.

1986. New theories of multinational enterprises: An assessment of internalisation theory. Bulletin of

Economic Research, 38:101-118. 
D.J. Lecraw \& L.D. Booth. 1985. International business: Firm and environment. New York: McGraw Hill.

Scott, B.R. \& G.R. Lodge, eds. US competitiveness in the world economy. Boston: Harvard Business School Press.

Stopford, J. 1982. The world directory of multinational enterprises. Basingstoke: MacMillan.

Sullivan, J.J. and I. Nonaka. 1986. The application of organizational learning theory to Japanese and American management. Journal of International Business Studies, Fall:127-147.

Teece, D.J. 1981. The multinational enterprise: Market failure and market power considerations. Sloan Management Review, 22:3-17.

1983. Technological and organizational factors in the theory of the multinational enterprise. In M.C. Casson, ed., Growth of international business. London: Allen \& Unwin.

. 1986. Transaction cost economics and the multinational enterprise. Journal of Economic Behaviour and Organization, 7:21-45.

, ed. 1987. The competitive challenge. Cambridge, Mass.: Ballinger.

Tharakan, P.K.M. 1984. The economics of intra-industry trade. Amsterdam: North Holland.

Tolentino, P. 1987. The global shift in international production: The growth of multinational enterprises from the developing countries: The Philippines. Ph.D. thesis, University of Reading.

Vernon, R. 1974. The location of economic activity. In J.H. Dunning, Economic analysis and the multinational enterprise. London: Allen and Unwin.

1983. Organizational and institutional responses to international risk. In R.J. Herring, ed., Managing international risk. Cambridge: CUP.

1985. Comment on chapter by J.H. Dunning and G. Norman. In A. Erdilek, ed., Multinationals as mutual invaders. London: Croom Helm.

Williamson, O. 1981. The modern corporation: Origins, evolution, attributes. Journal of Economic Literature, 19:1537-68.

Young, S., N. Hood \& J. Hamill. 1985. Decision making. In Foreign owned multinational subsidiaries in the United Kingdom. Geneva: ILO Working Paper No. 35. 